\title{
Drying kinetics and thin layer modeling of ogi produced from six maize varieties at varying soaking period and drying temperature
}

\author{
${ }^{1}$ Bolaji, O.T, ${ }^{1}$ Adepoju, P.A. ${ }^{2}$ Adelana, E.O. and ${ }^{3}$ Adesina, B.S. \\ ${ }^{1}$ Department of Food Technology, Lagos State Polytechnic Ikorodu, Lagos \\ ${ }^{2}$ Department of Food Technology, Yaba College of Technology, Lagos \\ ${ }^{3}$ Department of Agricultural and Environmental Engineering, Lagos State Polytechnic, Ikorodu, Lagos
}

Article history:

Received: 22 March 2020

Received in revised form: 3

June 2020

Accepted: 8 June 2020

Available Online: 13 August 2020

Keywords:

Ogi,

Drying kinetics,

Drying temperature,

Activation energy,

Effective moisture diffusivity

DOI:

https://doi.org/10.26656/fr.2017.5(1).129

\begin{abstract}
The drying kinetics of ogi produced from six varieties of maize at varying soaking period $(12,24$ and $36 \mathrm{hrs})$ and drying temperature of 40,50 and $60^{\circ} \mathrm{C}$, respectively were studied. Seven common thin layer models were evaluated, and the best models were selected. The moisture content of ogi decreased with increased drying temperature and drying time while the drying rate increased with an increase in drying temperature and decreased with an increase in drying time. Logarithmic and two term models best fitted about 40.77\% (22 samples each). However, where two term models were selected best, the $\mathrm{R}^{2}$ values ranged from 0.9858-0.99999999, $\chi^{2}=0.03715-0.000412$, RMSE $=0.02206-0.0000677$, unlike Logarithmic model that ranged from 0.8876-0.9964, $\chi^{2}=0.07045-0.001447$, RMSE $=$ 0.1084-0.01098. There was no definite pattern for effective moisture diffusivity $\left(\mathrm{D}_{\text {eff }}\right)$ and Activation energy $\left(E_{a}\right)$. This research work strongly suggests that the drying process was predominantly in the falling rate period (FRP) and was significantly affected by the change in temperature and moisture gradient. The activation energy obtained for ogi at varying soaking period and drying temperature ranged from $2.58-12.00 \mathrm{~kJ} / \mathrm{mol}$ (A4Y), 7.72-44.95 kJ/mol (A4W), 14.53-35.88 kJ/mol (S7Y), 6.02-20.10 kJ/mol (D2Y), 14.024$45.31 \mathrm{~kJ} / \mathrm{mol}$ (DIY) and 19.34-64.22 kJ/mol (T3W). It was obviously indicated in this research that the soaking period had less or no impact on the drying behavior of ogi compared with the influence of drying temperature, drying time and initial moisture content.
\end{abstract}

\section{Introduction}

Application of dehydration is relevant in many food processes, particularly in food preservation. This is often achieved by removing or reducing moisture capable of aiding some undesirable reactions, deterioration and spoilage (Maskan et al., 2002; Simal et al., 2005; Sahin and Dincer, 2005). Drying process of food may be a complex dynamic of simultaneous heat and mass transfer (Bart-Plange et al., 2012). Apart from the strong potential for drying operation to prolong shelf-life of the product, it encourages volume reduction, product diversity, ease of transportation and distribution (BartPlange et al., 2012). Drying may aid the production of high-density product which can conveniently and adequately be packaged to prolong the shelf-life. These products can easily and rapidly be reconstituted without significant loss in some quality characteristics (Maskan, 2001; Maskan et al., 2002; Shi et al., 2008). However, physical changes, chemical reactions and alteration in sensory characteristics of some food products during and after drying operation have been reported (Ansari et al., 2004; Shi et al., 2008).

Two major possible stages (Constant-rate drying period and falling rate drying period) were widely reported in the literature (Maskan et al., 2002; Sahin and Dincer, 2005; Shi et al., 2008). The common relevant properties reported useful in the study and behavior of drying operations are moisture diffusivity, thermal conductivity, density, specific heat capacity, interphase heat and mass transfer coefficients (Maskan et al., 2002; Shi et al., 2008). Description and prediction of drying process of food are often possible with the aid of drying models (Midelli et al., 2002; Babalis and Belessiotis, 2004; Karim and Hawlader, 2005; Akpinar et al., 2006; Shi et al., 2008). Thin-layer drying models have found wide application because few parameters are needed in their computation (Maskan, 2001; Maskan et al., 2002; Kingsly et al., 2007; Erenturk and Erenturk, 2007; Shi et 
al., 2008).

Some of the thin layer models reported in the literature were for drying of Chilli pepper, millets samples, Sesame seeds, Amaranth grain, hazelnut, green pepper, green bean, squash, apricot, green chilli, pistachio, apple, pumpkin, red pepper, eggplant, bay leaves, rosehip, strawberries, green beans, okra, carrots, bananas and many other food materials (Yaldiz and Ertekin, 2001; Hossain and Bala, 2002; Midilli and Kucuk, 2003; Togrul and Pehlivan, 2003; Ertekin and Yaldiz, 2004; Erenturk et al., 2004; Sacilik and Unal, 2005; Gunhan et al., 2005; Doymaz, 2005; Karim and Hawlader, 2005; Toyosi and Adeladun, 2010; Ojendiran and Raji, 2010; Ronoh et al., 2010).

Ogi slurry is the product obtained from the fermentation of cereal and important in the Nigerian and West African diet (Bolaji et al., 2017). The process consists of soaking the maize for as long as $96 \mathrm{hrs}$ (Bolaji et al., 2014; Bolaji et al., 2015; Bolaji et al., 2017). Large scale production may be indispensable either in the dried or wet form basically for the growing population, the increased female (mothers) working force, the need for an alternative source of weaning food and increased shelf life. The Ogi material could be dried and packaged in polythene bags (Bolaji et al., 2014; Bolaji et al., 2015). The drying process and behavior of Ogi cannot be independent of its thermal properties, some of which were investigated by Bolaji et al. (2015).

The drying pattern of Ogi produced from yellow and white maize with the aid of oven and cabinet dryers were earlier attempted at $50^{\circ} \mathrm{C}$ (Bolaji et al., 2014), however effect of varietal influences, soaking period and varying drying temperature were not evaluated. In most cases of application of thin-layer drying, fine particles are rarely attempted as done in this research work. Past works were limited to cereal and legumes grains, fruits and vegetables with larger area compared to individual fine particles sizes of the milled slurry of ogi which are between 0.212-0.6 microns. The thin layer drying models application for these fine grains were rarely computed however attempted by Bolaji et al. (2014) for ogi produced from white and yellow maize grains and dried at a temperature of $50^{\circ} \mathrm{C}$. Varying soaking period and drying temperature and about six different maize breeds were employed in this research and this should give reliable representative for industrial application.

\section{Material and method}

Six maize varieties were obtained from the Institute of Agricultural Research and Training (IAR \& $\mathrm{T}$ ) Ibadan. As shown below

$\begin{array}{ll}\text { Codes } & \text { Bred Name } \\ \text { D1Y- } & \text { DMR-LSR } \\ \text { D2Y- } & \text { DMR-ESR-Y } \\ \text { T3W- } & \text { TZPB-SR-W } \\ \text { A4Y- } & \text { ART/98/SW1-SR-Y } \\ \text { A5W- } & \text { ART/98/SW5-OB-W } \\ \text { S7Y- } & \text { SUWAN-SR-Y }\end{array}$

About $1 \mathrm{~kg}$ of each maize variety was weighed, cleaned and soaked in water for 12, 24 and $36 \mathrm{hrs}$, respectively. It was wet-milled using 230 watts attrition mill, sieved and wet ogi obtained. The ogi was squeezed using a muslin cloth to reduce the moisture content. The initial moisture content of wet ogi obtained from each maize variety at the varying soaking period was determined using moisture analyzer Model 0HAUS MB45 $\left(10\right.$ mins at $\left.100^{\circ} \mathrm{C}\right)$. These were dried in Genlab drying cabinet, model DC 125 at 40,50 and $60^{\circ} \mathrm{C}$. The dried ogi was further milled using laboratory mill IKA model M20 and sieved through $212 \mu \mathrm{m}$ mesh.

\subsection{Drying kinetics computation}

Drying kinetics of the process was studied, and curve fitted with selected models as shown in Table 1. The drying constant and coefficients of the models were determined by non-linear regression analysis with the aid MATLAB 2017. Drying experiments were expressed of dimensionless form as moisture ratios MR as shown in equation (1) (Shivhare et al., 2000; Özbek and Dadali, 2007):

$$
M R=\frac{M-M_{e}}{M_{i}-M_{e}}=\exp (-k t)
$$

Where $\mathrm{M}$ is the moisture content at any time, $\mathrm{M}_{\mathrm{i}}$ is the initial moisture content and $\mathrm{M}_{\mathrm{e}}$ is the equilibrium moisture content (Thakor et al., 1999; Togrul and Pehlivan, 2002; Akgun and Doymaz, 2005). The nonlinear regression analysis in the present study was performed using MATLAB 2017. The goodness of fit of the tested mathematical models from the experimental data was evaluated with correlation coefficient $\left(R^{2}\right)$, the reduced chi-square $\left(\chi^{2}\right)$ and the root mean square error (RMSE). The higher the values of the $\mathrm{R}^{2}$, and lower values of the $\chi^{2}$ and RMSE, the better the goodness of fit (Yaldiz and Ertekin, 2001; Gunhan et al., 2005; Sacilik and Unal, 2005). The reduced $\chi^{2}$ and RMSE were computed as shown in equations (2) and (3)

$$
\begin{aligned}
R M S E & =\left\lceil\left.\frac{1}{N} \sum_{I=1}^{N}\left(M R_{\text {pred }, i}-M R_{\text {exp },}\right)^{2}\right|^{1 / 2}\right. \\
x^{2} & =\frac{\sum_{i=1}^{n}\left(M R_{\left.e_{\text {exp }, i}-M R_{\text {pre }, i}\right)}\right.}{N-n}
\end{aligned}
$$

\subsection{Estimation of effective moisture diffusivities}

The effective diffusivities of the drying process of ogi were estimated by the method reported for drying 
Table 1. Selected mathematical models for drying curves fitting

\begin{tabular}{cll}
\hline S/n & Model & \multicolumn{1}{c}{ Mathematical expressions } \\
\hline 1 & Lewis & $M R=\exp (-k t)$ \\
2 & Page & $M R=a \cdot \exp (-k t)$ \\
3 & Herderson and Pabis & $M R=a \cdot \exp \left(-k_{0} t\right)+b \cdot \exp \left(-k_{1} t\right)$ \\
4 & Two term model & $M R=1+a t+b t^{2}$ \\
5 & Wang and Singh & $M R=a * \exp (-b t)+c$ \\
6 & Logarithmic & $M R=a * \exp (-b t)+b * c$ \\
7 & Midelli et al. &
\end{tabular}

characteristics of biological products in falling rate period using Fick's diffusion equation (4) (Flores et al., 2012)

$$
M R=\frac{8}{\pi^{2}} \sum_{n=1}^{\infty} \frac{1}{n^{2}} \exp \left[-n^{2} \frac{\pi^{2} D_{\text {efft }}}{r^{2}}\right]
$$

Where MR is the moisture ratio, $D_{\text {eff }}$ is the effective moisture diffusivity $\left(\mathrm{m}^{2} / \mathrm{s}\right), r$ is the equivalent radius $(\mathrm{m})$ and $t$ is the time (s). This could be written in a logarithmic form as shown in Equation (5). The effective moisture diffusivity was calculated from the slope of a straight line when experimental data in terms of $\ln (\mathrm{MR})$ were plotted against drying time (Flores et al., 2012):

$$
\ln M R=\ln \frac{8}{\pi^{2}}-\left(\frac{\pi}{r}\right)^{2} D_{\text {eff }} t
$$

The effective moisture diffusivity was estimated by using the method of slopes. From Equation (5), a plot of $\operatorname{lnMR}$ versus drying time is expected to give a straight line with a slope as written in equation (6)

$$
\text { Slope }=\frac{\pi^{2} D_{\text {eff }}}{r^{2}}
$$

\section{Result and discussion}

\subsection{Moisture content}

The moisture content of ogi decreased with an increase in drying temperature and drying time. The moisture decreased significantly $(\mathrm{p}<0.05)$ for all drying temperatures. A similar observation was noted for computed moisture ratio. There were higher drying rates at high moisture contents. These decreased rapidly with decreased moisture content. This may be unconnected with the free moisture near the surface of the product. The changes in moisture content are as shown in Table 2.

The moisture content of drained ogi slurry ranged from 44.59 to $47.27 \%$. This work revealed that drying temperature had an impact on the drying time of ogi, irrespective of the soaking period. The drying time of ogi slurry produced from all the maize varieties at 12,24 and $36^{\text {th }}$ hour of soaking ranged from $17-19,13-15$ and 9-11 hrs at 40,50 and $60^{\circ} \mathrm{C}$, respectively. There was no significant difference in the initial moisture content of drained ogi.

The moisture decrease followed a similar trend reported by Bolaji et al. (2014). The changes in the moisture content appeared to be the function of drying temperature and time as shown in Figure 1. Initially, there was a rapid decrease in moisture content with increased drying time. This then slowly decreased with an increase in the drying time. Falling rate periods was noticeably dominant in the drying of ogi in this experiment.

However, the drying time to attain respective final moisture content decreased with increased drying temperature. This is consistent with the findings of some researchers (Doymaz, 2005; Karim and Hawlader, 2005; Akpinar et al., 2006; Kingsly et al., 2007; Erenturk and Erenturk, 2007; Shi et al., 2008; Bolaji et al, 2014).

According to Demirel and Turhan (2003), the prevalent fallen rate periods observed in this experiment indicated that the drying rate was effectively governed by internal resistance within the ogi slurry. It can be deduced that there was a decrease in moisture migration with an increase in drying time. (Demirel and Turhan, 2003; Doymaz, 2005; Karim and Hawlader, 2005; Akpinar et al., 2006).

The increased drying rate observed most especially at the beginning of the drying may be due to the increased heat transfer potential within the drying environment because of increased temperature (Maskan, 2001; Akpinar et al., 2006; Waewsak et al., 2006). The drying rate presented in Figure 2 also followed a similar trend reported for drying of ogi by Bolaji et al. (2014). Also, food composition was reported among factors that may affect the rate of water removal in the food materials. Some researchers reported that surface-tovolume ratio of the food can minimize the resistance to heat and mass transfer (Maskan, 2001; Maskan et al., 2002; Akpinar et al., 2006; Erenturk and Erenturk, 2007) while Chirife (1983) reported that drying behavior may be a function of the equipment employed in the dehydration operation. 
Table 2. Initial and moisture content of ogi

\begin{tabular}{|c|c|c|c|c|c|c|c|}
\hline \multirow{2}{*}{ Maize Variety } & \multirow{2}{*}{ Drying Temperature } & \multicolumn{3}{|c|}{ Initial Moisture Content (\%) } & \multicolumn{3}{|c|}{ Final Moisture Content (\%) } \\
\hline & & $12 \mathrm{hrs}$ & $24 \mathrm{hrs}$ & $36 \mathrm{hrs}$ & $12 \mathrm{hrs}$ & $24 \mathrm{hrs}$ & $36 \mathrm{hrs}$ \\
\hline $\mathrm{D} 2 \mathrm{Y}$ & 40 & 46.54 & 46.22 & 44.47 & $8.44^{\text {bcde }}$ & $8.51^{\text {bcde }}$ & $7.87^{\mathrm{de}}$ \\
\hline $\mathrm{D} 2 \mathrm{Y}$ & 50 & 44.97 & 44.59 & 45.15 & $7.89^{\text {ef }}$ & $7.82^{\mathrm{ef}}$ & $7.80^{\mathrm{de}}$ \\
\hline $\mathrm{D} 2 \mathrm{Y}$ & 60 & 44.21 & 44.85 & 41.96 & $8.12^{\text {def }}$ & $8.36^{\mathrm{def}}$ & $8.49^{\text {bcde }}$ \\
\hline A5W & 40 & 45.9 & 45.45 & 45.71 & $7.86^{\text {ef }}$ & $8.29^{\mathrm{def}}$ & $8.11^{\mathrm{dce}}$ \\
\hline A5W & 50 & 45.62 & 44.44 & 44.82 & $8.16^{\text {def }}$ & $8.05^{\mathrm{ef}}$ & $7.82^{\mathrm{de}}$ \\
\hline A $5 W$ & 60 & 44.94 & 43.35 & 41.16 & $7.27^{\mathrm{f}}$ & $8.25^{\mathrm{def}}$ & $7.85^{\mathrm{de}}$ \\
\hline A4W & 40 & 42.74 & 44.36 & 44.45 & $9.06^{\mathrm{abc}}$ & $7.92^{\mathrm{ef}}$ & $7.79^{\mathrm{de}}$ \\
\hline A4W & 50 & 43.32 & 42.72 & 44.14 & $8.96^{\mathrm{abcd}}$ & $7.92^{\mathrm{ef}}$ & $8.79^{\mathrm{ab}}$ \\
\hline A4W & 60 & 45.41 & 44.99 & 44.47 & $9.69^{a}$ & $8.36^{\text {bcde }}$ & $9.65^{\mathrm{a}}$ \\
\hline DIY & 40 & 44.16 & 47.25 & 44.21 & $8.18 \mathrm{~d}^{\mathrm{ef}}$ & $7.83^{\text {ef }}$ & $7.51^{\mathrm{e}}$ \\
\hline DIY & 50 & 45.63 & 43.95 & 44.39 & $8.05^{\text {cdef }}$ & $7.93^{\mathrm{ef}}$ & $7.81^{\mathrm{de}}$ \\
\hline DIY & 60 & 45.01 & 43.489 & 43.61 & $7.73^{\text {ef }}$ & $7.97^{\mathrm{ef}}$ & $7.61^{\mathrm{e}}$ \\
\hline S7Y & 40 & 44.51 & 45.74 & 44.86 & $7.92^{\text {ef }}$ & $8.94^{\text {abcd }}$ & $9.18^{\mathrm{abc}}$ \\
\hline S7Y & 50 & 44.77 & 46.31 & 44.51 & $9.45^{\mathrm{a}}$ & 7.66 & 9.07 \\
\hline S7Y & 60 & 47.27 & 44.67 & 43.47 & $9.58^{\mathrm{a}}$ & 7.56 & $9.35^{\mathrm{ab}}$ \\
\hline $\mathrm{T} 3 \mathrm{~W}$ & 40 & 44.98 & 44.05 & 44.38 & $7.74^{\mathrm{ef}}$ & 7.47 & $8.14^{\mathrm{dce}}$ \\
\hline $\mathrm{T} 3 \mathrm{~W}$ & 50 & 45 & 44.623 & 45.59 & $9.23^{\mathrm{ab}}$ & 8.64 & $7.88^{\mathrm{de}}$ \\
\hline $\mathrm{T} 3 \mathrm{~W}$ & 60 & 44.34 & 44.06 & 44.59 & $8.35^{\text {bcde }}$ & 9.15 & $8.65^{\mathrm{abcd}}$ \\
\hline
\end{tabular}

Mean with same superscripts along the column are not significantly different at ( $\mathrm{p}>0.05)$

\subsection{Thin layer models}

The drying curves fitted to the experimental data using seven selected models as shown in Table 1 resulted in summarized best models selected based on recommended criteria are as shown in Tables 3, 4 and 5 . The constant parameters are $\mathrm{a}, \mathrm{b}$ and $\mathrm{c}$ while drying constants is $\mathrm{k}$, respectively. The $\mathrm{R}^{2,} \mathrm{RSME}$ and chisquare $\left(\chi^{2}\right)$ were used to determine the best model. The best model for ogi produced from $\mathrm{A} 5 \mathrm{~W}$ and dried at $40^{\circ} \mathrm{C}(12$ and $24 \mathrm{hrs}), 50^{\circ} \mathrm{C}(12,24$ and $36 \mathrm{hrs})$ and $60^{\circ} \mathrm{C}$ (12 hrs) were best fitted with Logarithmic model with higher $\mathrm{R}^{2}$, lowest $\chi^{2}$ and RMSE. While ogi dried at $60^{\circ} \mathrm{C}$ ( 24 and $36 \mathrm{hrs}$ ) of soaking were best fitted with two term and Wang and Singh models, respectively. Apart from ogi dried at $60^{\circ} \mathrm{C}(12 \mathrm{hrs}), 50^{\circ} \mathrm{C}(36 \mathrm{hrs})$ and $40^{\circ} \mathrm{C}(12$ and $24 \mathrm{hrs}$ ) which were best fitted with Logarithmic model, others were best fitted with two term models.

Ogi produced from $\mathrm{A} 5 \mathrm{~W}\left(60^{\circ} \mathrm{C}\right)$ at $36^{\text {th }}$ hour of soaking and dried at $60^{\circ} \mathrm{C}$, DIY $\left(60^{\circ} \mathrm{C}\right)$ at $12^{\text {th }}$ hour of Soaking, DIY $\left(50^{\circ} \mathrm{C}\right)$ at $24 \mathrm{hrs}$ of soaking, S7Y $\left(50^{\circ} \mathrm{C}\right)$ at $24^{\text {th }}$ hour of soaking, $\mathrm{T} 3 \mathrm{~W}\left(40^{\circ} \mathrm{C}\right)$ at $12 \mathrm{hrs}$ of soaking and $\mathrm{T} 3 \mathrm{~W}\left(40^{\circ} \mathrm{C}\right)$ were best fitted with Wang and Singh model. Dried ogi (DIY) produced at $12^{\text {th }}$ hour of soaking and dried at $60^{\circ} \mathrm{C}, \mathrm{S} 7 \mathrm{Y}$ at produced 12 and $36^{\text {th }}$ hour of Soaking and dried at 60 and $40^{\circ} \mathrm{C}$, respectively were best fitted with Page models. Logarithmic and Two term models best fitted about $40.77 \%$ (22) samples each of ogi produced from six varieties, soaked and dried at varying period and temperature, respectively. However, where two term models were noted and selected best based on the recommended criteria, were relatively and significantly highest for $\mathrm{R}^{2}$, lowest for $\chi^{2}$ and RMSE, respectively when compared with Logarithmic models. The values for two term model ranged from 0.9858$0.99999999, \chi^{2}=0.03715-0.000412$, RMSE 0.022060.0000677, unlike Logarithmic model which ranged from 0.8876-0.9964, $\chi^{2}=0.07045-0.001447$, RMSE, 0.1084-0.01098. The values of $\mathrm{R}^{2}$ obtained for two term model were within the range reported for drying of apple (Akpinar et al., 2006); green table olives Demir et al. (2007), and black grapes (Doymaz 2006).

\subsection{Effective moisture diffusivity and activation energy}

The effective moisture diffusivity and Activation energy is as shown in Table 6. Moisture diffusivity obtained for ogi slurry and dried at varying temperature ranged from $1.97-2.01 \times 10^{-10} \mathrm{~m}^{2} / \mathrm{s}, 1.16-2.77 \times 10^{-10} \mathrm{~m}^{2} /$ $\mathrm{s}$ and $1.3-2.00 \times 10^{-10} \mathrm{~m}^{2} / \mathrm{s}(\mathrm{A} 4 \mathrm{Y}), 2.96-5.05 \times 10^{-10} \mathrm{~m}^{2} / \mathrm{s}$ $2.66-4.91 \times 10^{-10} \mathrm{~m}^{2} / \mathrm{s}$, and $1.1-4.46 \times 10^{-10} \mathrm{~m}^{2} / \mathrm{s}(\mathrm{A} 5 \mathrm{~W})$, $2.81-3.19 \times 10^{-10} \mathrm{~m}^{2} / \mathrm{s}, 1.3-7.61 \times 10^{-10} \mathrm{~m}^{2} / \mathrm{s}$ and $2.23-$ $3.35 \times 10^{-10} \mathrm{~m}^{2} / \mathrm{s}(\mathrm{S} 7 \mathrm{Y}), 2.57-2.95 \times 10^{-10} \mathrm{~m}^{2} / \mathrm{s}, 1.82-2.92 \mathrm{x}$ $10^{-10} \mathrm{~m}^{2} / \mathrm{s}$ and $2.23-2.44 \times 10^{-10} \mathrm{~m}^{2} / \mathrm{s}$ (D2Y), $4.65-10 \times 10$ ${ }^{-10} \mathrm{~m}^{2} / \mathrm{s}, 1.86-6.24 \times 10^{-10} \mathrm{~m}^{2} / \mathrm{s}$ and $2.05-3.61 \times 10^{-10} \mathrm{~m}^{2} / \mathrm{s}$ and $2.35-3.82 \times 10^{-10} \mathrm{~m}^{2} / \mathrm{s}, 1.05-2.95 \times 10^{-10} \mathrm{~m}^{2} / \mathrm{s}$ and $2.04-3.45 \times 10^{-10} \mathrm{~m}^{2} / \mathrm{s}(\mathrm{T} 3 \mathrm{~W})$. These values were within values reported by some researchers (Yashoda et al., 2006; Gastón et al., 2004; Doymaz, 2005; Gely and Santalla, 2007; Rahman et al., 2009; Gaware et al., 2010). Past work established that variation in effective 

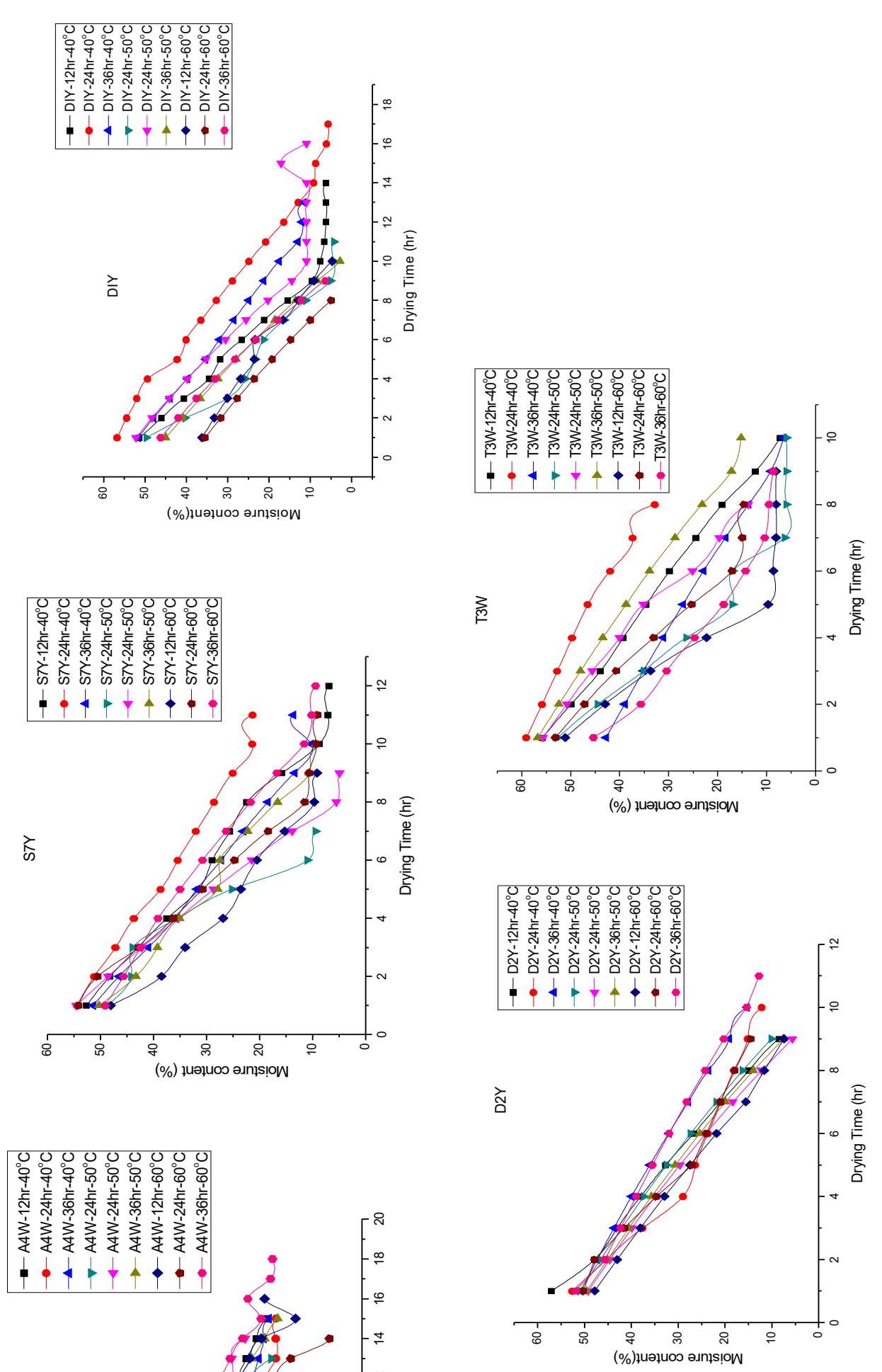

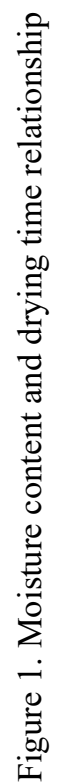




Table 3. Summarised statistical results of the best fitted drying models for dried ogi from A5W and A4Y

\begin{tabular}{|c|c|c|c|c|c|c|c|c|c|c|c|}
\hline $\begin{array}{c}\text { Drying } \\
\text { temperature }\end{array}$ & $\begin{array}{l}\text { Soaking } \\
\text { period }\end{array}$ & Best model & $\mathrm{a}$ & $\mathrm{b}$ & $\mathrm{c}$ & $\mathrm{n}$ & $\mathrm{K}_{1}$ & $\mathrm{~K}_{2}$ & $\mathrm{R}^{2}$ & $\chi^{2}$ & RMSE \\
\hline \multirow[t]{3}{*}{ A5W (40) } & 12 & Logarithmic & 1.231 & 0.08612 & -0.1492 & & & & 0.984 & 0.02208 & 0.03715 \\
\hline & 24 & Logarithmic & 2.806 & 2.701 & -1.904 & & & & 0.992 & 0.00853 & 0.02666 \\
\hline & 36 & Two term & 0.8955 & -0.02714 & & & -0.05651 & 0.1294 & 0.9991 & 0.001063 & 0.008416 \\
\hline \multirow[t]{3}{*}{ A5W (50) } & 12 & Logarithmic & 3.588 & 0.02855 & -2.664 & & & & 0.9915 & 0.008531 & 0.02978 \\
\hline & 24 & Logarithmic & 0.9407 & 0.1525 & -0.1787 & & & & 0.9867 & 0.005848 & 0.02704 \\
\hline & 36 & Logarithmic & 1.852 & 0.07057 & -0.8726 & & & & 0.9961 & 0.003295 & 0.0203 \\
\hline \multirow[t]{3}{*}{ A5W (60) } & 12 & Logarithmic & 3.969 & $1.13 \mathrm{E}-03$ & -3.884 & & & & 0.9979 & 0.002322 & 0.01205 \\
\hline & 24 & Two term & -0.1334 & 0.8476 & & & 0.1227 & -0.04202 & 0.9999 & $3.75 \mathrm{E}-05$ & 0.002314 \\
\hline & 36 & $\begin{array}{l}\text { Wang and } \\
\text { Singh }\end{array}$ & -0.06524 & -0.00199 & & & & & 0.9988 & 0.001064 & 0.01087 \\
\hline \multirow[t]{3}{*}{ A4Y (40) } & 12 & Logarithmic & 5.335 & 0.01259 & -4.37 & & & & 0.9957 & 0.004435 & 0.01922 \\
\hline & 24 & Logarithmic & 3.008 & 0.02822 & -1.963 & & & & 0.9935 & 0.008487 & 0.02659 \\
\hline & 36 & Two term & -0.3529 & 1.251 & & & 0.05352 & -0.01962 & 0.9996 & 0.000315 & 0.005349 \\
\hline \multirow[t]{3}{*}{ A4Y (50) } & 12 & Two term & -0.7833 & 1.402 & & & 0.08056 & 0.04169 & 0.9959 & 0.002261 & 0.01434 \\
\hline & 24 & Two term & 0.8298 & -0.1145 & & & -0.0304 & 0.08033 & 0.99999 & 0.000011 & 0.0009841 \\
\hline & 36 & Logarithmic & 3.856 & 0.01064 & -3.251 & & & & 0.9964 & 0.001446 & 0.01098 \\
\hline \multirow[t]{3}{*}{ A4Y (60) } & 12 & Logarithmic & 1.141 & 0.08218 & -0.3267 & & & & 0.9719 & 0.02113 & 0.04197 \\
\hline & 24 & Two term & -0.3529 & 1.251 & & & 0.05352 & -0.01962 & 0.9996 & 0.000315 & 0.005349 \\
\hline & 36 & Two term & -0.00014 & 0.761 & & & 0.4591 & -0.09423 & 0.9987 & 0.000642 & 0.007639 \\
\hline
\end{tabular}

Table 4. Summarised Statistical results of the best fitted drying models for dried ogi produced from DIY AND S7Y

\begin{tabular}{|c|c|c|c|c|c|c|c|c|c|c|c|}
\hline $\begin{array}{c}\text { Drying } \\
\text { temperature }\end{array}$ & $\begin{array}{c}\text { Soaking } \\
\text { period }\end{array}$ & Best model & $\mathrm{a}$ & $\mathrm{b}$ & $\mathrm{c}$ & $\mathrm{n}$ & $\mathrm{K}_{1}$ & $\mathrm{~K}_{2}$ & $\mathrm{R}^{2}$ & $\chi^{2}$ & RMSE \\
\hline \multirow[t]{3}{*}{ D1Y (40) } & 12 & $\begin{array}{c}\text { Wang and } \\
\text { Singh }\end{array}$ & -0.1354 & 0.004421 & & & & & 0.9851 & 0.0166 & 0.03719 \\
\hline & 24 & Logarithmic & 2.888 & 0.02342 & -1.984 & & & & 0.99210 & 0.00986 & 0.02654 \\
\hline & 36 & Logarithmic & 2.125 & 0.04625 & -1.082 & & & & 0.9957 & 0.004112 & 0.02028 \\
\hline \multirow[t]{3}{*}{ D1Y (50) } & 12 & Logarithmic & 1.147 & 0.2898 & -0.00601 & & & & 0.8876 & 0.07045 & 0.1084 \\
\hline & 24 & $\begin{array}{c}\text { Wang and } \\
\text { Singh }\end{array}$ & -0.125 & 0.004362 & & & & & 0.9681 & 0.03497 & 0.04828 \\
\hline & 36 & Two Term & -0.1779 & 0.9164 & & & 0.1174 & -0.05209 & 0.99999 & 0.0000015 & 0.000549 \\
\hline \multirow[t]{3}{*}{ D1Y (60) } & 12 & page & & 0.02849 & & 1.916 & & & 0.9703 & 0.04539 & 0.0615 \\
\hline & 24 & Two Term & 0.8888 & -0.2613 & & & -0.04469 & 0.1076 & 0.999999 & 0.00000068 & 0.000412 \\
\hline & 36 & Two Term & -0.193 & 0.9542 & & & 0.1248 & -0.04698 & 0.999999 & 0.0000088 & 0.001326 \\
\hline \multirow[t]{3}{*}{ S7Y (40) } & 12 & Logarithmic & 3.353 & 0.02804 & -2.326 & & & & 0.9935 & 0.008702 & 0.02813 \\
\hline & 24 & Logarithmic & 3.671 & 0.0115 & -254.5 & & & & 0.9955 & 0.001809 & 0.01228 \\
\hline & 36 & page & & 0.03145 & & 1.673 & & & 0.9918 & 0.01007 & 0.02897 \\
\hline \multirow[t]{5}{*}{ S7Y (50) } & 12 & page & & 0.06197 & & 1.707 & & & 0.9763 & 0.02958 & 0.04965 \\
\hline & 24 & $\begin{array}{c}\text { Wang and } \\
\text { Singh }\end{array}$ & -1.471 & 2.303 & & & & & 0.9964 & 0.003348 & 0.0183 \\
\hline & 36 & Logarithmic & 3.747 & 0.01097 & -286.3 & & & & 0.9964 & 0.001447 & 0.01098 \\
\hline & 24 & Two term & -0.3529 & 1.251 & & & 0.05352 & -0.01962 & 0.9996 & 0.000315 & 0.005349 \\
\hline & 36 & Two term & -0.00014 & 0.761 & & & 0.4591 & -0.09423 & 0.9987 & 0.000642 & 0.007639 \\
\hline
\end{tabular}


Table 5. Summarised statistical results of the best fitted drying models for dried ogi from T3W and D2Y

\begin{tabular}{cccccccccccc}
\hline $\begin{array}{c}\text { Drying } \\
\text { temperature }\end{array}$ & $\begin{array}{c}\text { Soaking } \\
\text { period }\end{array}$ & Best model & $\mathrm{a}$ & $\mathrm{b}$ & $\mathrm{c}$ & $\mathrm{n}$ & $\mathrm{K}_{1}$ & $\mathrm{~K}_{2}$ & $\mathrm{R}^{2}$ & $\chi^{2}$ & $\mathrm{RMSE}$ \\
\hline T3W (40) & 12 & Wang and Singh & -0.13 & 0.00423 & & & & & 0.9842 & 0.01734 & 0.03801 \\
& 24 & Two Term & -0.111 & 1.344 & & & 0.1808 & -0.0278 & 0.9992 & 0.000209 & 0.00723 \\
& 36 & Logarithmic & 1.842 & 0.06162 & -0.9419 & & & & 0.9842 & 0.01958 & 0.04219 \\
T3W (50) & 12 & Wang and Singh & -0.187 & 0.00858 & & & & & 0.9788 & 0.02328 & 0.04404 \\
& 24 & two term & -2.212 & 3.155 & & & 0.05776 & 0.0182 & 0.9945 & 0.002604 & 0.02551 \\
& 36 & Logarithmic & 5.961 & 0.01775 & -4.836 & & & & 0.9773 & 0.04561 & 0.06439 \\
T3W (60) & 12 & page & & 0.1049 & & 1.75 & & & 0.9639 & 0.03582 & 0.05463 \\
& 24 & Logarithmic & 1.869 & 0.1204 & -0.5552 & & & & 0.9805 & 0.01519 & 0.05513 \\
& 36 & Two Term & 2.323 & 2.323 & & & -0.1415 & -0.1931 & 0.9924 & 0.005589 & 0.03052 \\
D2Y (40) & 12 & Two Term & -0.013 & 2.402 & 0.3019 & -0.14 & 0.3019 & -0.1404 & 0.9985 & 0.005817 & 0.02883 \\
& 24 & Logarithmic & 0.9317 & 0.1855 & -0.0294 & & & & 0.994 & 0.003886 & 0.0188 \\
& 36 & Two Term & -1.443 & 2.412 & & & 0.03307 & -0.0054 & 0.9996 & 0.000441 & 0.007 \\
D2Y (50) & 12 & Two Term & 1.16 & -0.1463 & & & -0.0633 & 0.1023 & 0.9955 & 0.02585 & 0.02585 \\
& 24 & Two Term & 0.9456 & -0.19 & & & -0.0315 & 0.1002 & 1 & 0.0 .0000073 & 0.0009 \\
& 36 & Two Term & 1.116 & -0.244 & & & -0.0313 & 0.0967 & 1 & 0.0000049 & 0.00074 \\
D2Y (60) & 12 & Two Term & -2.068 & 3.024 & & & 0.01912 & -0.01 & 0.9989 & 0.001085 & 0.01098 \\
& 24 & Logarithmic & 2.553 & 0.03033 & -1.619 & & & & 0.9931 & 0.004978 & 0.02231 \\
& 36 & Two Term & -0.002 & 0.9279 & & & 0.3373 & -0.1165 & 0.9978 & 0.001501 & 0.01291 \\
\hline
\end{tabular}

Table 6. Effective moisture diffusivity $\left(\mathrm{D}_{\text {eff }}\right)$ and activation energy $\left(\mathrm{E}_{\mathrm{a}}\right)$ of ogi produced from varieties at varying soaking period

\begin{tabular}{|c|c|c|c|c|c|c|c|}
\hline $\begin{array}{c}\text { Soaking } \\
\text { period }(\mathrm{hr})\end{array}$ & $\begin{array}{c}\text { Drying } \\
\text { Temperature }\end{array}$ & $\begin{array}{c}\text { A4Y } \\
\left(\times 10^{-10}\right) \mathrm{m}^{2} / \mathrm{s}\end{array}$ & $\begin{array}{c}\text { A5W } \\
\left(\times 10^{-10}\right) \mathrm{m}^{2} / \mathrm{s}\end{array}$ & $\begin{array}{c}\text { S7Y } \\
\left(\times 10^{-10}\right) \mathrm{m}^{2} / \mathrm{s}\end{array}$ & $\begin{array}{c}\text { D2Y } \\
\left(\times 10^{-10}\right) \mathrm{m}^{2} / \mathrm{s}\end{array}$ & $\begin{array}{c}\text { D1Y } \\
\left(\times 10^{-10}\right) \mathrm{m}^{2} / \mathrm{s}\end{array}$ & $\begin{array}{c}\mathrm{T} 3 \mathrm{~W} \\
\left(\times 10^{-10}\right) \mathrm{m}^{2} / \mathrm{s}\end{array}$ \\
\hline \multirow[t]{3}{*}{12} & 40 & 1.97 & 2.96 & 3.19 & 2.57 & 4.65 & 3.27 \\
\hline & 50 & 2.01 & 4.41 & 2.81 & 2.83 & 4.44 & 3.82 \\
\hline & 60 & 2.09 & 5.05 & 6.8 & 2.95 & 10 & 2.35 \\
\hline \multirow[t]{3}{*}{24} & 40 & 2.5 & 2.66 & 1.3 & 2.91 & 2.2 & 1.05 \\
\hline & 50 & 1.16 & 4.91 & 7.61 & 2.92 & 1.86 & 2.7 \\
\hline & 60 & 2.77 & 3.15 & 2.89 & 1.82 & 6.24 & 2.95 \\
\hline \multirow[t]{3}{*}{36} & 40 & 1.3 & 1.1 & 2.49 & 2.44 & 2.05 & 3.45 \\
\hline & 50 & 2 & 4.46 & 2.23 & 2.23 & 2.99 & 2.04 \\
\hline & 60 & 1.71 & 3.05 & 3.5 & 2.14 & 3.61 & 3.31 \\
\hline \multicolumn{8}{|c|}{ Activation Energy $\left(\mathrm{E}_{\mathrm{a}}\right)$} \\
\hline $\begin{array}{c}\text { Soaking } \\
\text { period (hr) }\end{array}$ & & $\begin{array}{c}\text { A4Y } \\
(\mathrm{J} / \mathrm{mol})\end{array}$ & $\begin{array}{c}\text { A5W } \\
(\mathrm{J} / \mathrm{mol})\end{array}$ & $\begin{array}{c}\text { S7Y } \\
(\mathrm{J} / \mathrm{mol})\end{array}$ & $\begin{array}{c}\mathrm{D} 2 \mathrm{Y} \\
(\mathrm{J} / \mathrm{mol})\end{array}$ & $\begin{array}{c}\text { D1Y } \\
(\mathrm{J} / \mathrm{mol})\end{array}$ & $\begin{array}{c}\mathrm{T} 3 \mathrm{~W} \\
(\mathrm{~J} / \mathrm{mol})\end{array}$ \\
\hline 12 & & 2589.25 & 23265.4 & 32394.4 & 6019.59 & 14024.25 & 193439.3 \\
\hline 24 & & 3759.12 & 7724.45 & 35881.6 & 20106.46 & 45310.1 & 64224.65 \\
\hline 36 & & 12005.1 & 44955.8 & 14531.5 & 5717.969 & 2269.775 & 373783.3 \\
\hline
\end{tabular}

moisture diffusivity may be affected by types and conditions of experimental procedures employed for the determination of effective moisture diffusivity, data treatment methods, temperature, product properties, compositions, physiological state and heterogeneity of structure (Celma et al., 2007). Contrary to the report of Celma et al. (2007), values obtained in this research work did not suggest that temperature increase caused increase in effective moisture diffusivity. The structure of ogi from different varieties may be responsible for this.

The values of activation energy obtained using Arrhenius type equation is as shown in Table 6. The values obtained were within reported values for Agricultural products (Bablis et al., 2004; Aghbashlo et al., 2008). The activation energy obtained for ogi at varying soaking period and drying temperature are in the range of $2.58-12.00 \mathrm{~kJ} / \mathrm{mol}$ (A4Y), 7.72-44.95 kJ/mol (A4W), 14.53-35.88 kJ/mol (S7Y),6.02-20.10 kJ/mol (D2Y),14.024-45.31 kJ/mol (DIY) and 19.34-64.22 kj/ $\mathrm{kJ} / \mathrm{mol}(\mathrm{T} 3 \mathrm{~W})$. Higher values of activation energy were obtained for ogi produced at $24^{\text {th }}$ hour of soaking for all maize varieties with the exception of ogi produced from $\mathrm{A} 4 \mathrm{Y}$ and $\mathrm{A} 5 \mathrm{~W}$ at $12^{\text {th }}$ hour of soaking.

\section{Conclusion}


Drying operation of ogi was significantly affected by the change in temperature and moisture gradient. There was reduced drying time with the increase in drying temperature. There was a higher removal of water at the initial stage of the drying operation and drying process was predominantly in the falling rate period (FRP). The soaking period had no significant impact on drying behavior. Drying behavior was more connected with the amount of moisture in the drained ogi and the drying temperature. The structure of ogi slurry may have played an active role in the drying kinetics and effective moisture diffusivity, this may need to be investigated. Logarithmic and two term models best fitted about 40.77 $\%$ (22 samples each). There was no definite pattern for effective moisture diffusivity $\left(D_{\text {eff }}\right)$ and Activation energy $\left(E_{a}\right)$.

\section{References}

Aghbashlo, M. Kianmehr, M.H. and Samimi-Akhijahani, H. (2009). Evaluation of thin-layer drying models for describing drying kinetics of barberries (Barberries vulgaris). Journal of Food Process Engineering, 32 (2), 278 - 293. https://doi.org/10.1111/j.17454530.2007.00216.x

Akgun, N.A. and Doymaz, I. (2005). Modeling of olive cake thin-layer drying process. Journal of Food Engineering, 68(4), 455-461. https:// doi.org/10.1016/j.jfoodeng.2004.06.023

Akpinar, E.K. and Bicer, Y. (2006). Mathematical modelling and experimental study on thin layer drying of strawberry. International Journal of Food Engineering, 2(5), 1-11. https:// doi.org/10.2202/1556-3758.1045

Ansari, F.A., Abbas, K.A. and Ahmad, M.M.H. (2004). Correlation between thermal diffusivity variation and quality of cold preserved fish. ASEAN Journal on Science and Technology for Development, 21(1), 110. https://doi.org/10.29037/ajstd.82

Babalis, S.J. and Belessiotis, V.G. (2004). Influence of drying conditions on the drying constants and moisture diffusivity during the thin-layer drying of figs. Journal of Food Engineering, 65(3), 449-458. https://doi.org/10.1016/j.jfoodeng.2004.02.005

Bart-Plange, A.I., Addo, A., Ofori, H. and Asare, V. (2012). Thermal Properties of Gros Michel Banana Grown in Ghana. ARPN Journal of Engineering and Applied Sciences, 7(4), 478-484.

Bolaji, O.T., Olalusi, A.P. and Adesina, B.S. (2015). Mathematical Modeling of Drying Pattern of $O g i$ Produced from Two Types of Maize Grain. Journal of Food Research, 4(1),174-185. https:// doi.org/10.5539/jfr.v4n1p174
Bolaji, O.T., Awonorin, S.O., Shittu, T.A. and Sann, L.O. (2017). Changes induced by soaking period on the physical properties of maize in the production of Ogi.

Cogent Food and Agriculture, 3(1), 4-14. https:// doi.org/10.1080/23311932.2017.1323571

Bolaji, O.T. Oyewo, A.O. and Adepoju P.A. (2014). Soaking and Drying Effect on the Functional Properties of Ogi Produce from Some Selected Maize Varieties. American Journal of Food Science and Technology, 2(5), 150-157. https:// doi.org/10.12691/ajfst-2-5-3

Celma, A.R., Rojas, S., López, F., Montero, I. and Miranda, T. (2007). Thin-layer drying behaviour of sludge of olive oil extraction. Journal of Food Engineering, 80(4), 1261-1271. https:// doi.org/10.1016/j.jfoodeng.2006.09.020

Demirel, D. and Turhan, M. (2003) Air-drying behavior of Dwarf Cavendish and Gros Michel banana slices. Journal of Food Engineering, 2003, 59(1), 1-11. https://doi.org/10.1016/S0260-8774(02)00423-5

Doymaz, I. (2005). Drying behaviour of green beans. Journal of Food Engineering, 69(2),161-165. https:// doi.org/10.1016/j.jfoodeng.2004.08.009

Erenturk, S. and Erenturk, K. (2007). Comparison of genetic algorithm and neural network approaches for the drying process of carrot. Journal of Food Engineering, 78(3), 905-912. https:// doi.org/10.1016/j.jfoodeng.2005.11.031

Erenturk, S., Gulaboglu, M.S. and Gultekin, S. (2004). The thin-layer drying characteristics of rosehip. Biosystems Engineering, 89(2), 159-166. https:// doi.org/10.1016/j.biosystemseng.2004.06.002

Ertekin, C. and Yaldiz, O. (2004). Drying of eggplant and selection of a suitable thin layer drying model. Journal of Food Engineering, 63, 349-359. https:// doi.org/10.1016/j.jfoodeng.2003.08.007

Flores, M.J.P., Febles V.G., Pérez, J.J.C., Dominguez, G., Mendez, J.V.M., Gonzalez E.P. and Lopez G.F.G. (2012). Mathematical modelling of castor oil seeds (Ricinus communis) drying kinetics in fluidized bed at high temperatures. Indian Crop Production, 38, 64-71. https://doi.org/10.1016/ j.indcrop.2012.01.008

Gastón, A.L., Abalone, R.M., Giner, S.A. and Bruce, D.M. (2004). Effect of modelling assumptions on the effective water diffusivity in wheat. Biosystems Engineering, 8(2), 175-185. https://doi.org/10.1016/ j.biosystemseng.2004.02.009

Gaware, T.J., Sutar, N. and Thorat, B.N. (2010). Drying of tomato using different methods: comparison of dehydration and rehydration kinetics. Drying 
Technology, 289(5), 651-658. https:// doi.org/10.1080/07373931003788759

Gely, M.C. and Santalla, E.M. (2007) Moisture diffusivity in quinoa (Chenpodiun quinoa Willd.) seeds: Effect of air temperature and initial moisture content of seeds. Journal of Food Engineering, 78 (3), 1029-1033. https://doi.org/10.1016/ j.jfoodeng.2005.12.015

Gunhan, T., Demir, V., Hancioglu, E. and Hepbasli, A. (2005). Mathematical modelling of drying of bay leaves. Energy Conversion and Management, 46 (11), 1667-1679. https://doi.org/10.1016/ j.enconman.2004.10.001

Hossain, M.A. and Bala, B.K. (2002). Thin-layer drying characteristics for green chilli. Drying Technology, 20(2), 489-505. https://doi.org/10.1081/DRT120002553

Karim, M.A. and Hawlader, M.N.A. (2005). Drying characteristics of banana: Theoretical and experimental validation. Journal of Food Engineering, 70(1), 35 - 45. https://doi.org/10.1016/ j.jfoodeng.2004.09.010

Kingsly, R.P., Goyal, R.K., Manikantan, M.R. and Ilyas, S.M. (2007). Effects of pretreatments and drying air temperature on drying behavior of peach slice. International Journal of Food Science and Technology, 42(1), 65-69. https://doi.org/10.1111/ j.1365-2621.2006.01210.x

Maskan, A. Kaya, S. and Maskan, M. (2002). Hot air and sun drying of grape leather. Journal of Food Engineering, 54(1), 81-88. https://doi.org/10.1016/ S0260-8774(01)00188-1

Maskan, M. (2001). Drying, shrinkage, and rehydration characteristics of Kiwi fruits during hot air and microwave drying. Journal of Food Engineering, 48 (2), 177-182. https://doi.org/10.1016/S0260-8774 (00)00155-2

Midilli, A. and Kucuk, H. (2003). Mathematical modelling of thin layer drying of pistachio by using solar energy. Energy Conversion and Management, 44(7), 1111-1122. https://doi.org/10.1016/S01968904(02)00099-7

Özbek, B. and Dadali, G. (2007). Thin-layer drying characteristics and modeling of mint leaves undergoing microwave treatment. Journal of Food Engineering, 83(4), 541-549. https:// doi.org/10.1016/j.jfoodeng.2007.04.004

Ojendiran, J.O. and Raji, A.O. (2010). Thin layer drying of millet and effect of temperature on drying characteristics. International Food Research Journal, 17, 1095-1106.

Rahman, M.S., Al-Shamsi, Q.H., Bengtsson, G.B.,
Sablani, S.S. and Al-Alawi, A. (2009). Drying kinetics and allicin potential in garlic slices during different methods of drying. Drying Technology, 27 (3), 467-477. https:// doi.org/10.1080/07373930802683781

Ronoh, E.K., Kanali, C.L., Mailutha, J.T. and Shitanda, D. (2010). Thin layer drying kinetics of Amaranth grains in a natural convection solar tent dryer. Journal of Food Agriculture Nutrition and Development, 10(3), 2218-2233. https:// doi.org/10.4314/ajfand.v10i3.54080

Sacilik, K. and Unal, G. (2005). Dehydration Characteristics of Kastamonu Garlic Slices. Biosystems Engineering, 92(2), 207-215. https:// doi.org/10.1016/j.biosystemseng.2005.06.006

Sahin, A.Z. and Dincer, I. (2005). Prediction of drying times for irregular shaped multi-dimensional moist solids. Journal of Food Engineering, 71(1), 119 126. https://doi.org/10.1016/j.jfoodeng.2004.10.024

Shi, Q.-L., Chang-Hu, X., Ya, Z., Zhao-Jie, L. and Wang, X. (2008). Drying Characteristics of horse mackerel (Trachurus japonicus) dried in a heat pump dehumidifier. Journal of Food Engineering, 84(1), $12-20$. https://doi.org/10.1016/ j.jfoodeng.2007.04.012

Togrul, I.T. and Pehlivan, D. (2003). Modeling of drying kinetics of single apricot. Journal of Food Engineering, 58(1), 23-32. https://doi.org/10.1016/ S0260-8774(02)00329-1

Toyosi, Y.T. and Adeladun, A. (2010). Air drying characteristics of chili pepper. International Journal Food Engineering, 6(1), 1-15. https:// doi.org/10.2202/1556-3758.1649

Yaldiz, O. and Ertekin, C. (2001). Thin layer solar drying of some vegetables. Drying Technology, 19 (2), 583-596. https://doi.org/10.1081/DRT100103936

Yashoda, H.M., Prabha, T.N. and Tharanathan, R.N. (2006). Mango ripening: changes in cell wall constituents in relation to textural softening. Journal of the Science of Food and Agriculture, 86(5), 713721. https://doi.org/10.1002/jsfa.2404 